Trinity University

Digital Commons@ Trinity

Biology Faculty Research

Biology Department

$1-2014$

\title{
Honesty of a Dynamic Female Aggressive Status Signal: Baseline Testosterone Relates to Bill Color in Female American Goldfinches
}

T T. Pham

Trinity University

Philip Queller

TrinityUniversity, pqueller@utexas.edu

KA. Tarvin

Troy G. Murphy

Trinity University, tmurphy@trinity.edu

Follow this and additional works at: https://digitalcommons.trinity.edu/bio_faculty

Part of the Biology Commons

\section{Repository Citation}

Pham T. T., Queller P. S., Tarvin K. A., Murphy T. G. (2014). Honesty of a dynamic female aggressive status signal: baseline testosterone relates to bill color in female American goldfinches. Journal of Avian Biology, 45(1), 22-28. doi:10.1111/ j.1600-048X.2013.00286.x 


\title{
Honesty of a dynamic female aggressive status signal: baseline testosterone relates to bill color in female American goldfinches
}

\author{
T. T. Pham, P. S. Queller, K. A. Tarvin and T. G. Murphy \\ T. T. Pham, P. S. Queller and T. G. Murphy (troy.murphy@trinity.edu), Dept of Biology, Trinity Univ., San Antonio, TX 78212, USA. \\ - K. A. Tarvin, Dept of Biology, Oberlin College, Oberlin, OH 44074, USA.
}

\begin{abstract}
Status signals are linked to fighting ability and enable competitors to gain access to resources without risking injury in aggressive combat. The relationship between testosterone (T), a hormone that mediates aggression, and signals of status is well studied in males, but little is known about the relationship between $\mathrm{T}$ and female signals of status. Female and male American goldfinches Spinus tristis express a dynamic carotenoid-based orange bill color during the breeding season and previous work has demonstrated that females use orange bill color to communicate competitive ability during intrasexual competition. We test the hypothesis that female bill color reflects baseline $\mathrm{T}$, which would allow receivers to directly assess a competitor's aggressive potential. We found a positive relationship between $\mathrm{T}$ and bill coloration in females, indicating that bill color has the ability to signal female competitive status. This finding is consistent with the hypothesis that female bill color is a reliable signal of fighting ability, and indicates that females, like males, may use coloration to signal their hormonally mediated aggressive potential.
\end{abstract}

Ornamental traits are often used to communicate fighting or competitive ability during agonistic interactions (i.e. signals of status, sensu Rohwer 1975). Recent research has demonstrated that females may evolve social signals (reviewed by Amundsen 2000, Amundsen and Pärn 2006, Tarvin and Murphy 2012), and that these signals are often used during competitive interactions (Kraaijeveld et al. 2007, Tobias et al. 2012). Like males, females often compete over limited resources such as breeding resources (Watson and Simmons 2010), high-quality mates (Langmore et al. 1996), and paternal care (Sandell and Smith 1997). In addition, both sexes compete over non-breeding resources (West-Eberhard 1979, 1983, Rubenstein 2012), such as food (Crowhurst et al. 2012) and foraging territories (Wolf 1969, Murphy et al. 2009a). Because individuals of both sexes risk injury during agonistic encounters, signals of status are likely to be favored by selection in both sexes (Lyon and Montgomerie 2012). These signals mediate aggressive interactions during face-to-face competition for access to resources and enable competitors to assess a potential opponent's fighting ability without risking injury (reviewed by Senar 2006). Although there have been many studies on the signal value and evolutionary maintenance of status signals in males (Rohwer 1977, Pryke and Andersson 2003, Chaine and Lyon 2008), fewer studies have focused on female status signals (Swaddle and Witter 1995, Jones and Hunter 1999, Kraaijeveld et al. 2004, Murphy et al. 2009b), and the honesty enforcing mechanisms underlying these female status signals have rarely been tested.
Much research has focused on whether male status signals are mediated by testosterone (T) (Bókony et al. 2008, McGlothlin et al. 2008, Evans et al. 2012), an androgen that regulates development of secondary sexual characters as well as a suite of behavioral characteristics including aggression (Adkins-Regan 2005). When status signal expression is linked to $\mathrm{T}$, signal intensity can honestly reflect signaler fighting ability in two potentially overlapping ways. First, the signal can directly reflect an individual's aggressive potential and thus its preparedness to enter into an agonistic interaction. Second, the honesty of testosterone-dependent status signals can be maintained because $T$ imposes production and maintenance costs that limit signal expression (Grafen 1990, Folstad and Karter 1992). There is evidence that male signals of status may be expressed in proportion to both $\mathrm{T}$ titers and aggressiveness (Rohwer and Rohwer 1978, Ligon et al. 1990, Evans et al. 2000, Ardia et al. 2010); however, it is unclear whether female status signals are similarly related to physiological investment in this aggression-regulating hormone (but see Eens et al. 2000, Muck and Goymann 2011).

Both male and female American goldfinches Spinus tristus have a colorful carotenoid based orange bill during the breeding season. Although bill color is similarly expressed in both males and females, previous work indicates that bill color functions as an intra-sexual signal of status among females (Murphy et al. 2009b), while studies on status signaling among male goldfinches indicate that male bill color does not mediate agonistic interactions (Murphy and Tarvin unpubl.). Bill coloration of both sexes is dynamic and can 
change in response to stressors, over a period as short as $6.5 \mathrm{~h}$ (Rosenthal et al. 2012, also see Rosen and Tarvin 2006). Bill color of both sexes also changes (becomes more dull) rapidly in response to experimentally induced infection (Rosenthal et al. 2012). Furthermore, bill color of non-manipulated birds is negatively correlated with stress, as assessed by heterophil:lymphocyte ratio (Kelly et al. 2012), and among females (but not males), bill color is positively correlated with both immunoglobulins, a measure of constitutive adaptive immunity, and with natural antibodies, a measure of innate immunity (Kelly et al. 2012). Although this previous work has provided evidence for condition-dependent expression of dynamic bill color, it remains unclear whether $T$ affects within-breeding season color variation. One line of evidence suggests that bill color responds in a T-dependent manner, at least on a gross-scale: bill color of both sexes changes from gray-brown to orange before the breeding season, and this seasonal change in color is partially mediated by $\mathrm{T}$ (Mundinger 1972). The influence of $T$ on gross seasonal changes in color suggests that inter-individual differences during the breeding season may also be regulated by $\mathrm{T}$. As such, the American goldfinch provides a unique opportunity to understand how $\mathrm{T}$ relates to the honesty of a status signal that is used exclusively by females.

In the current study, we test for a correlation between baseline $\mathrm{T}$ and bill coloration in female American goldfinches. Based on evidence that female bill color is a signal of status (Murphy et al. 2009b), we predict that baseline T is positively correlated with carotenoid-based bill color in females. In addition, we explore the relationship between $\mathrm{T}$ and bill color in males. We studied this relationship during the pre-laying period, which is the time of the annual cycle when female bill color is used to mediate competitive interactions (Murphy et al. 2009b), and when there is competition over resources such as breeding sites and food.

\section{Material and methods}

\section{Species}

The American goldfinch is a socially monogamous passerine with bi-parental care, and typically produces a single brood per season (McGraw and Middleton 2009). In southern Ontario, where our study was conducted, pairs initiate their first clutches in early July. Both males and females are aggressive in this species: both sexes defend an area immediately surrounding the nest (Stokes 1950, Coutlee 1967) and compete for food in communal feeding areas (Popp 1987). Females appear to be more aggressive than males during the nesting period (Coutlee 1967), although the ecological contexts of this female-biased dominance are unclear.

\section{General}

This study was carried out in southern Ontario, Canada, near the Queens Univ. Biological Station $\left(44^{\circ} 33^{\prime} \mathrm{N}, 76^{\circ} 19^{\prime} \mathrm{W}\right)$. We captured adult females and males using mist nests and traps placed around Nyjer seed feeders. We used only adult birds (ASY) in the study; sex and age-class were determined by plumage (Pyle 1997). Birds were captured and sampled for $T$ and bill color prior to clutch initiation, from 11 June to 3 July 2011. Bill coloration at this time of year has already undergone its seasonal change from grey to orange, and the orange color has reached its peak extent across the bill.

Upon capture, we collected basic morphometrics and objectively measured bill color. All measures of bill color were taken within $1 \mathrm{~h}$ of capture because bill color can change rapidly (Rosenthal et al. 2012). Bill color was measured with an Ocean Optics USB2000 + spectrometer and PX-2 pulsed xenon lamp. The probe was mounted in a holder that minimized ambient light and positioned the tip of the probe approximately $7 \mathrm{~mm}$ from the surface of the bill. The probe was held $90^{\circ}$ to the bill surface, and measured an area approximately $2 \mathrm{~mm}$ in diameter. Measures of reflectance were taken at five different, haphazardly chosen locations on left side of the upper mandible. Reflectance $(R)$ was quantified as the proportion of light reflected off the bill, compared to our Spectralon white standard. The white standard was protected in a housing to prevent the transfer of oil and dirt from the bill to the standard. The spectrometer was calibrated against this standard before measuring the bill color of each bird. We created a mean reflectance curve (from the five measurements) and calculated mean brightness (i.e. luminance; mean $R$ from 320 to $700 \mathrm{~nm}$, hereafter 'brightness'), hue (wavelength where $R=\left[R_{\max }+R_{\min }\right] / 2$ ), and yellow-orange saturation ([sum of $R$ from 550 to $625 \mathrm{~nm}] /$ mean brightness) using RCLR ver. 0.9.33 (Montgomerie 2010); see Table 3.2 in Montgomerie (2006) for further details.

\section{Testosterone assay}

We sampled $\mathrm{T}$ from a total of 20 females and 29 males. We collected blood $(80-150 \mu \mathrm{l})$ from the brachial vein into heparinized microhematocrit tubes. In order to reduce the effect of stress on free $T$ (Deviche et al. 2001), blood was collected shortly after birds experienced capture stress (mean $\pm \mathrm{SE}=9.1 \pm 0.4 \mathrm{~min}$ ). Blood was stored at $4^{\circ} \mathrm{C}$ for up to $5 \mathrm{~h}$. Plasma was separated by centrifugation and then stored at $-80^{\circ} \mathrm{C}$ until $\mathrm{T}$ analyses.

Testosterone was assayed using Salimetrics competitive enzyme immunoassay (EIA). This EIA is widely used to assay testosterone from avian plasma, and has been validated for various passerines (Washburn et al. 2007), as well as for American goldfinches (Furlonger et al. 2012). We followed the Salimetrics protocol, but modified the concentration of source solution (plasma) so the samples were within the sensitive range of the standard curve. Our final dilutions were 1:8.3 for male plasma and 1:1.7 for female plasma. Plasma samples for each individual were run in duplicate, and the intra-assay coefficient of variation (CV) calculated from standard samples of known concentration, ranged from 2.8 to 8.2 (mean 4.6). Inter-assay CV was 10.

\section{Statistics}

To test for a relationship between baseline $T$ concentration and bill coloration in females and males, we used general linear models in JMP ver. 10.0.2. We included in statistical models the sampling date (date) to control for within season 
changes in hormone profiles and bill color, and time between capture and sampling (sample time) to control for possible effects of capture stress on free $\mathrm{T}$ levels. Factors were kept in the model if $\mathrm{p}<0.25$. Four males had $\mathrm{T}$ values that were greater than the sensitivity of our assay and so were assigned a value equivalent to the maximum detected $T$ within the sensitive range. To test whether this approach biased our results, we performed additional analyses wherein these males were excluded, and the results (shown below) were not qualitatively different.

\section{Results}

Females had significantly lower circulating $\mathrm{T}$ than males (mean $\pm \mathrm{SE}$; female $\mathrm{T}=0.04 \pm 0.01 \mathrm{ng} \mathrm{ml}^{-1}$; male $\mathrm{T}=1.47 \pm 0.17$ ng $\left.\mathrm{ml}^{-1} ; \mathrm{F}_{1,47}=46.9, \mathrm{p}<0.001\right)$. Bill color of females differed from males (Fig. 1): female bills were significantly less saturated in the yellow-orange range than male bills (females $=0.242 \pm 0.002$; males $=0.248 \pm 0.001 ; \mathrm{F}_{1,47}=6.13$, $\mathrm{p}=0.017$ ), although there was high degree of overlap in distribution between the sexes, and the most saturated bill in the sample was from a female (female range $=0.230-0.264$; male range $=0.231-0.262$ ). The sexes did not differ significantly in bill hue (females $=548.9 \pm 0.74$; males $=548.4 \pm 0.64$; $\mathrm{F}_{1,47}=0.30, \mathrm{p}=0.59$ ) or brightness (females $=0.28 \pm 0.01$; males $\left.=0.31 \pm 0.01 ; \mathrm{F}_{1,47}=3.16, \mathrm{p}=0.08\right)$.

\section{Female testosterone}

Among females, there was a significant positive relationship between $\mathrm{T}$ and saturation of the bill $\left(\mathrm{F}_{2,17}=7.3\right.$, model $\mathrm{p}=0.005$, sample time $\mathrm{p}=0.045$, testosterone $\mathrm{p}=0.009$, $R^{2}=0.46$; Fig. 2$)$. There was a non-significant negative trend between female $\mathrm{T}$ and bill hue $\left(\mathrm{F}_{1,18}=4.36\right.$, testosterone $\left.\mathrm{p}=0.051, R^{2}=0.20\right)$, and there was not a significant relationship between female $T$ and bill brightness $\left(F_{1,18}=0.45\right.$, testosterone $\mathrm{p}=0.51$; Fig. 2).

\section{Male testosterone}

Among males, there was not a significant relationship between $\mathrm{T}$ and bill saturation $\left(\mathrm{F}_{2,26}=1.95\right.$, model $\mathrm{p}=0.16$,

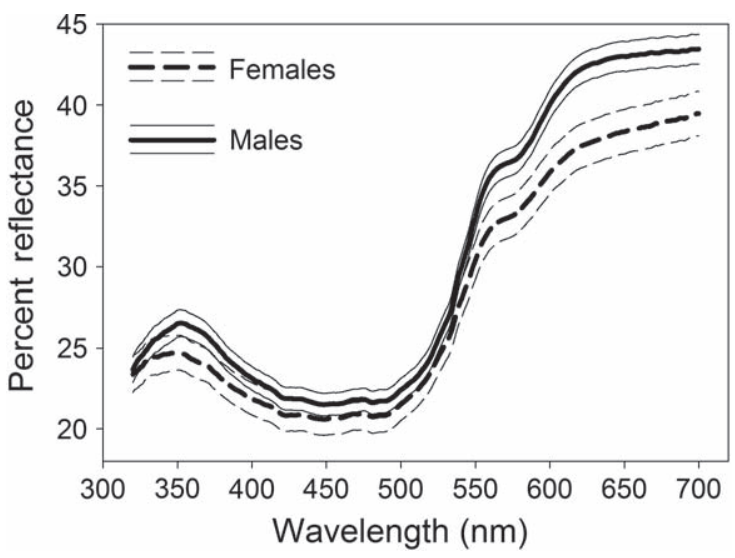

Figure 1. Average reflectance curves representing bill coloration of American goldfinch females (dashed line) and males (solid line). Thin lines are standard errors. date $\mathrm{p}=0.06$, testosterone $\mathrm{p}=0.99)$, hue $\left(\mathrm{F}_{1,27}=2.79\right.$, testosterone $\mathrm{p}=0.11)$, or brightness $\left(\mathrm{F}_{3,25}=3.98\right.$, model $\mathrm{p}=0.019$, date $\mathrm{p}=0.046$, sample time $\mathrm{p}=0.11$, testosterone $\mathrm{p}=0.20$, Fig. 2). When four males with unusually high $\mathrm{T}$ were removed from the analyses (Methods), results were similar: there was not a significant relationship between $\mathrm{T}$ and bill saturation among males $\left(\mathrm{F}_{2,22}=2.5\right.$, model $\mathrm{p}=0.11$, date $\mathrm{p}=0.04$, testosterone $\mathrm{p}=0.61)$, hue $\left(\mathrm{F}_{1,23}=2.63\right.$, testosterone $\mathrm{p}=0.12)$, or brightness $\left(\mathrm{F}_{3,21}=3.92\right.$, model $\mathrm{p}=0.022$, date $\mathrm{p}=0.035$, sample time $\mathrm{p}=0.17$, testosterone $\mathrm{p}=0.18)$.

\section{Discussion}

Little is known about whether female signals of competitive status are linked to testosterone (T), a hormone that is often implicated in mediating male aggression (Hau 2007) and is also thought to play a role in female aggression (Cain and Ketterson 2012, but see Elekonich and Wingfield 2000). Our study explored the relationship between circulating $\mathrm{T}$ and bill coloration, a signal that has been shown to communicate intrasexual competitive status in female American goldfinches (Murphy et al. 2009b). We found that female bill color is positively correlated with circulating testosterone, thus indicating that bill color has the potential to communicate hormonally mediated aggressive potential in females. This relationship suggests that bill color may be dependent on circulating testosterone, and that receivers can gain information about the likelihood of a potential rival engaging in physical altercations over resources, the level of investment into aggressive defense, as well as a rival's ability to sustain the T-related costs necessary to maintain a strong signal. Receivers could thus use bill color to assess an individual's physiological state, or its phenotypic condition, when deciding whether or not to enter into competitive interactions with an opponent.

The positive relationship between $\mathrm{T}$ and bill color in female goldfinches is consistent with earlier work on the influence of $\mathrm{T}$ on bill color in other species. For example, short-term experimental changes in $\mathrm{T}$ have been shown to cause rapid bill color changes in male and female zebra finches Taeniopygia guttata (McGraw 2006, also see example for males: Ardia et al. 2010) as well as in female European starlings Sturnus vulgaris (de Ridder et al. 2002) and female budgerigars Melopsittacus undulatus (Nespor et al. 1996). Furthermore, a study of American goldfinches showed that in both sexes, administration of exogenous $\mathrm{T}$ led to seasonal increases in orange coloration, while castration of males during the nesting season led to bill color change in the opposite direction (Mundinger 1972). Although Mundinger's (1972) study focused on gross seasonal changes in goldfinch bill color (grey vs orange), it indicates that goldfinch bill color is responsive to circulating $\mathrm{T}$, and adds support to the hypothesis that inter-individual differences in female goldfinch bill color are mediated by $\mathrm{T}$.

Hormonal regulation of aggression has been well studied in males (reviewed by Soma 2006), and baseline $\mathrm{T}$ often predicts both aggressive investment in agonistic encounters (Wingfield et al. 1990, Hau et al. 2000) and competitive outcomes (Johnsen and Zuk 1995). Among 

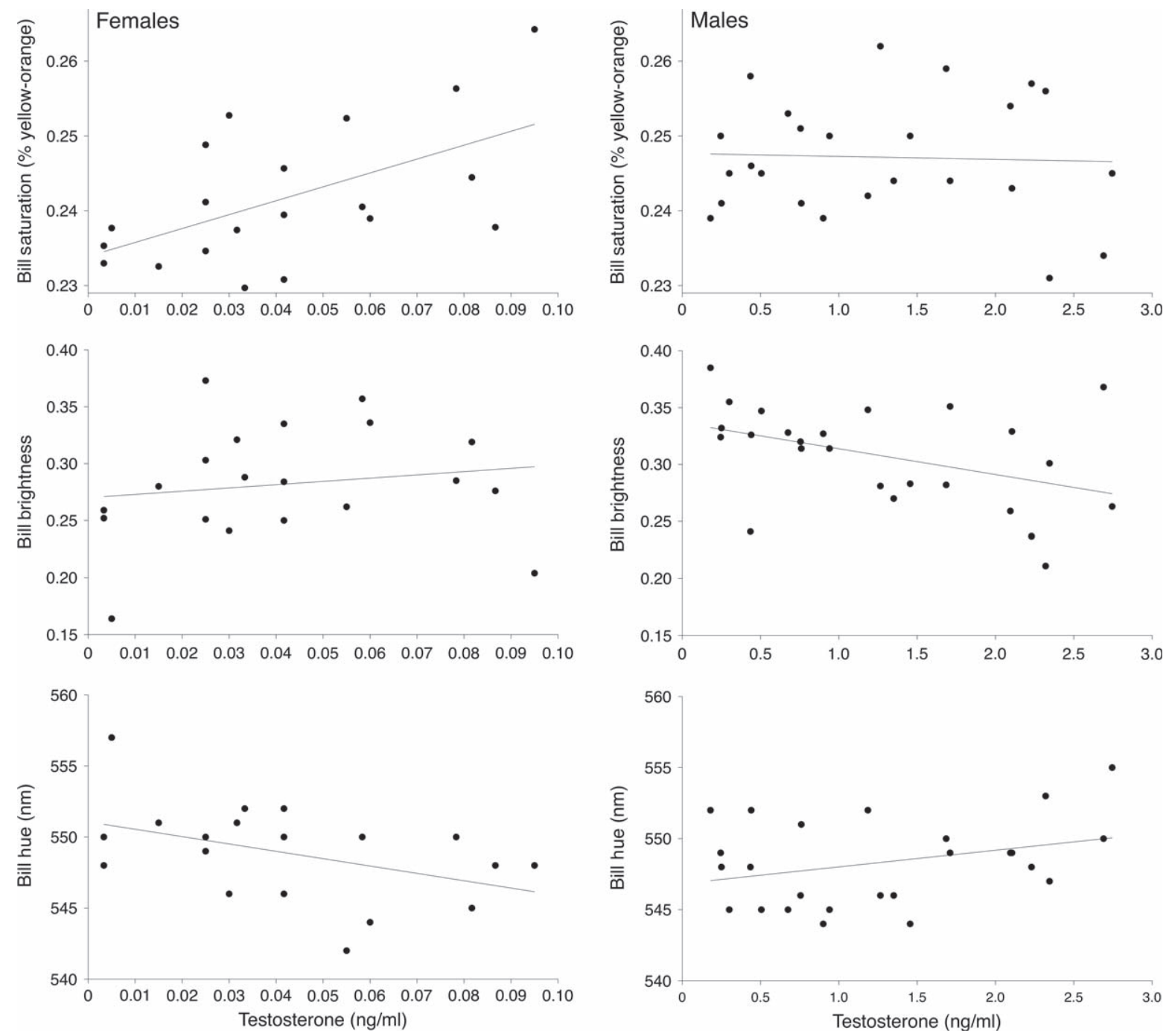

Figure 2. Relationship between baseline testosterone and bill color of female (left) and male (right) American goldfinches. There is a significant positive relationship between female testosterone and (a) orange-yellow saturation of the bill. Also shown are non-significant relationships between female testosterone and (b) bill brightness, and (c) bill hue. There is a non-significant relationship between male testosterone and (d) orange-yellow bill saturation, (e) brightness, and (f) hue. Note that the scale of the x-axis is different for females and males.

females, evidence suggests that aggression is also mediated by $\mathrm{T}$ (Langmore et al. 2002, Ketterson et al. 2005, Sandell 2007, Rosvall 2013), or by the downstream metabolite estradiol (Adkins-Regan 1999, Pärn et al. 2008). For example, females of colonial species have higher testosterone than non-colonial species (Møller et al. 2005), likely due to greater competition for nesting sites among colonial species. On an intraspecific level, female $T$ has been found to track the seasonal peak in aggression (red-winged blackbirds, Agelaius phoeniceus, Cristol and Johnsen 1994), and, among dark-eyed juncos Junco hyemalis, the ability to elevate $\mathrm{T}$ in response to a GNRH challenge is positively related to female aggression (Cain and Ketterson 2012). Furthermore, Gill et al. (2012) found that female buff-breasted wrens Thryothorus leucotis increased $\mathrm{T}$ levels in response to simulated territorial intrusion (STI) during the pre-breeding season, and others have found that administering $\mathrm{T}$ to females resulted in more aggression during STIs (Searcy 1988, Sandell 2007, Zysling et al. 2007). Furthermore, experimental administration of $\mathrm{T}$ to females increased relative domi- nance position within social flocks of domestic fowl Gallus domesticus (Allee et al. 1939). Although these studies suggest that $T$ plays a role in regulating aggression in females, other studies have failed to find a relationship between female $T$ and aggression (Elekonich and Wingfield 2000, Eens and Pinxten 2000, Jawor et al. 2006). As such, in some species, it seems likely that mechanisms other than testosterone may regulate female aggression (e.g. dehydroepiandrosterone \{DHEA\} Soma 2006, or progesterone, Goymann et al. 2008). However, in the species in which female $T$ relates to aggression, it seems reasonable to expect females to evolve signals that communicate their hormonal state so as to reduce their likelihood of entering into physical battle, which carry risks of injury, as well as loss of time and energy.

Female goldfinches with greater $\mathrm{T}$ have more saturated bill coloration, likely indicating that these females have more carotenoids deposited within their bill. In support of this conclusion, work by McGraw et al. (2004) and Hill et al. (2009) showed that male American goldfinches supplemented with carotenoids during the spring molt develop 
more colorful bills. Moreover, McGraw and Hill (2000) found that goldfinches infected with coccidian parasites develop less colorful orange bills, likely because this parasite interferes with carotenoid uptake. We sampled bill color and $\mathrm{T}$ just prior to the nesting season, when the melanin content of goldfinch bills is very low (i.e. bills are typically orange across their entire surface), and so it is likely that the positive correlation between circulating $\mathrm{T}$ and bill coloration reflects an interaction between $\mathrm{T}$ and carotenoids, and not between $\mathrm{T}$ and melanin, as has been found in other studies (Laucht et al. 2010, Karubian et al. 2011).

Experimental increases in $\mathrm{T}$ have been shown to elevate carotenoid concentrations in liver and plasma (Blas et al. 2006), and several recent studies have proposed mechanisms by which the bioavailability of carotenoids for coloring ornaments is linked to circulating T. After assimilating carotenoids from food, birds and other vertebrates bind carotenoids to lipoproteins, which are biochemical assemblies that transport lipids to peripheral tissues (McGraw and Parker 2006). Work by McGraw et al. (2006) showed that $\mathrm{T}$ upregulates lipoprotein production, and that exogenous $\mathrm{T}$ administration elevates both circulating cholesterol and carotenoids, as well as increases bill redness in male zebra finches. In contrast, the administration of flutamide, an anti-androgen, leads to downregulation of lipoprotein production, plasma carotenoid concentration, and bill color. Because natural levels of $\mathrm{T}$ circulating in the blood are able to predict lipoprotein profile, plasma carotenoid concentration, and bill color, McGraw et al. (2006) suggested that T controls the amount of lipoproteins available for carotenoid transport to peripheral tissues. As such, carotenoid transport itself may serve as the key regulatory mechanism for bill pigmentation, and $\mathrm{T}$ may provide a direct link between competitive ability and coloration of the carotenoid-based bill in female American goldfinches. Studies showing that experimental manipulation of androgens has a strong effect on carotenoid-based coloration of non-feather integument in other species are consistent with this T-carotenoid interaction hypothesis (e.g. European starling, Sturnus vulgaris, de Ridder et al. 2002; zebra finch Taeniopygia guttata, Ardia et al. 2010; red-legged partridge Alectoris rufa, AlonsoAlvarez et al. 2009; red grouse Lagopus lagopus, MartínezPadilla et al. 2010).

Our finding that circulating $\mathrm{T}$ is not correlated with bill color in males supports our earlier findings that bill color functions as a signal of competitive status in females, but not in males (Murphy et al. 2009b, unpubl.). Given the lack of evidence that male bill color functions as a status signal, it seems possible that male bill color is regulated by different mechanisms than female bill color. In support of this idea, McGraw (2006) found that the relationship between T and bill color differs between the sexes in zebra finches, wherein males with more $T$ have the most colorful bills, while females with the greatest amount of $\mathrm{T}$ have intermediate bill color. One possible explanation for this sexual difference in zebra finches is that there may be more localized effects of $T$ in female bills than there is in male bills, possibly due to greater receptor density in female bill tissue (sensu McGraw 2006). Although the relationship between $\mathrm{T}$ and bill color in zebra finches is different from what we find in goldfinches, the sexual differences seen in both species may indicate that the tradeoffs of maintaining high $\mathrm{T}$ can be met with different physiological responses in the sexes, and suggest that different aspects of physiological condition may be signaled by the two sexes. Likewise, we have shown elsewhere (Kelly et al. 2012) that female, but not male, goldfinch bill color is correlated with immunoglobulin Y levels (a component of adaptive immunity) and likewise female, but not male, plumage color was correlated with circulating natural antibodies (a component of innate immunity), suggesting sex-specific signaling systems exist in this species.

An alternative explanation for why only female goldfinch bill color is correlated with $\mathrm{T}$ relates to the extremely high levels of male circulating $\mathrm{T}$ : it is possible that male $\mathrm{T}$ is above a level at which the sensitivity of bill color responds. In other words, any increase in male $T$ above baseline levels may have no additional effect on bill color because the activation of androgen receptors is above an asymptotic level of T saturation. Although we are currently unable to resolve whether male signal expression is constrained in this manner, future studies may be able to clarify this issue by experimentally manipulating $T$ levels during the winter when bills are naturally gray-brown to determine whether a threshold exists above which bill color does not respond to exogenous $\mathrm{T}$.

Although we provide evidence that $\mathrm{T}$ is related to integument coloration in female goldfinches, we cannot rule out the possibility that another steroid or steroid metabolite other than $\mathrm{T}$ affects carotenoid-based coloration. For example, the aromatization of $\mathrm{T}$ to estradiol may play an important role in signal expression; however, Mundinger (1972) found no effect of estradiol on bill color change in American goldfinches. Alternatively the correlation between bill color and $\mathrm{T}$ could arise if some yet unexplored factor influences both bill color and circulating $T$. As such, further research is necessary to determine how $\mathrm{T}$ affects bill color in this species.

Among female American goldfinches, the positive correlation between $\mathrm{T}$ and carotenoid-based coloration may provide a direct physiological indication of a female's readiness to escalate an aggressive encounter - information that could be very useful to receivers when assessing whether to enter into a potentially costly fight. This correlational study represents the first step in understanding the role of T on bill color in this species. To further assess this hypothesis, future work should employ manipulative administration of exogenous testosterone, as well as further explore how female bill color is expressed in proportion to the likelihood or intensity of aggressive behavior. It is also worth considering that the dynamic nature of this signal may itself be important during contest competition, and future research should test whether dynamic signals are evolutionarily favored when real-time information on a competitor's level of aggression can have important fitness consequences to a receiver.

Acknowledgements - We are grateful to the following Trinity Univ. students for help collecting data: Jordan West, Richard Simpson, Aaron Rosenblatt and Lucy Cevallos, and we are grateful to Alissa Murphy and Caitlin Murphy for help in the field. We also thank Bob Montgomerie and the staff of QUBS for logistic support. We are grateful to Scott MacDougall-Shackleton, Kim Schmidt, Fran Bonier and Steve Schoech for feedback on hormone analysis, and to James Roberts and Jonathan King for use of lab 
space. TGM was supported by the Faculty Development Fund at Trinity Univ., and KAT was supported by a Research Status Appointment from Oberlin College. This study was approved by the Institutional Animal Care and Use Committee of Trinity Univ. (82009-TM3).

\section{References}

Adkins-Regan, E. 1999. Testosterone increases singing and aggression but not male-typical sexual partner preference in early estrogen treated female zebra finches. - Horm. Behav. 35: 63-70.

Adkins-Regan, E. 2005. Hormones and animal social behavior. - Princeton Univ. Press.

Allee, W. C., Collias, N. E. and Lutherman, C. Z. 1939. Modification of the social order in flocks of hens by the injection of testosterone propionate. - Physiol. Zool. 12: 412-440.

Alonso-Alvarez, C., Pérez-Rodríguez, L., García, J. T. and Viñuela, J. 2009. Testosterone-mediated tradeoffs in the old age: a new approach to the immunocompetence handicap and carotenoidbased sexual signalling. - Proc. R. Soc. B 276: 2093-2101.

Amundsen, T. 2000. Why are female birds ornamented? - Trends Ecol. Evol. 15: 149-155.

Amundsen, T. and Pärn, H. 2006. Female coloration in birds: a review of functional and non-functional hypotheses. - In: Hill, G. E. and McGraw, K. J. (eds), Bird coloration vol. 2: function and evolution. Harvard Univ. Press, pp. 280-345.

Ardia, D. R., Broughton, D. R. and Gleicher, M. J. 2010. Short-term exposure to testosterone propionate leads to rapid bill color and dominance changes in zebra finches. - Horm. Behav. 58: 526-532.

Blas, J., Pérez-Rodríguez, L., Bortolotti, G. R., Viñuela, J. and Marchant, T. A. 2006. Testosterone increases bioavailability of carotenoids: insights into the honesty of sexual signaling. - Proc. Natl Acad. Sci. USA 103: 18633-18637.

Bókony, V., Garamszegi, L. Z., Hirschenhauser, K. and Liker, A. 2008. Testosterone and melanin-based black plumage coloration: a comparative study. - Behav. Ecol. Sociobiol. 62: 1229-1238.

Cain, K. E. and Ketterson, E. D. 2012. Competitive females are successful females; phenotype, mechanism, and selection in a common songbird. - Behav. Ecol. Sociobiol. 66: 241-252.

Chaine, A. S. and Lyon, B. E. 2008. Intrasexual selection on multiple plumage ornaments in the lark bunting. - Anim. Behav. 76: 657-667.

Coutlee, E. L. 1967. Agonistic behavior in the American goldfinch. - Wilson Bull. 79: 89-109.

Cristol, D. A. and Johnsen, T. S. 1994. Spring arrival, aggression and testosterone in female red-winged blackbirds (Agelaius phoeniceus). - Auk 111: 210-214.

Crowhurst, C. J., Zanollo, V., Griggio, M., Robertson, J. and Kleindorfer, S. 2012. White flank spots signal feeding dominance in female diamond firetails, Stagonopleura guttata. Ethology 118: 63-75.

de Ridder, E., Pinxten, R., Mees, V. and Eens, M. 2002. Short- and long-term effects of male-like concentrations of testosterone on female European starlings (Sturnus vulgaris). - Auk 119: 487-497.

Deviche, P., Breuker, C. J. and Orchinik, M. 2001. Testosterone, corticosterone, and photoperiod interact to regulate plasma levels of binding globulin and free steroid hormone in dark-eyed juncos, Junco hyemalis. - Gen. Comp. Endocrinol. 122: 67-77.

Eens, M. and Pinxten, R. 2000. Sex-role reversal in vertebrates: behavioural and endocrinological accounts. - Behav. Process. 51: 135-147.

Eens, M., van Duyse, E., Berghman, L. and Pinxten, R. 2000. Shield characteristics are testosterone-dependent in both male and female moorhens. - Horm. Behav. 37: 126-134.
Elekonich, M. M. and Wingfield, J. C. 2000. Seasonality and hormonal control of territorial aggression in female song sparrows (Passeriformes: Emberizidae: Melospiza melodia). - Ethology 106: 493-510.

Evans, M. R., Goldsmith, A. R. and Norris, S. R. 2000. The effects of testosterone on antibody production and plumage coloration in male house sparrows (Passer domesticus). - Behav. Ecol. Sociobiol. 47: 156-163.

Evans, M. R., Goldsmith, A. R. and Norris, S. R. A. 2012. The effects of testosterone on antibody production and plumage coloration in male house sparrows (Passer domesticus). - Behav. Ecol. Sociobiol. 47: 156-163.

Folstad, I. and Karter, A. J. 1992. Parasites, bright males and the immunocompetence handicap. - Am. Nat. 139: 603-622.

Furlonger, A. A., Huynh, L., Luloff, T. W., Schmidt, K. L. and Macdougall-Shackleton, S. A. 2012. Effects of supplementation with preferred foods on the reproductive axis of American goldfinches (Spinus tristis). - Can. J. Zool. 90: 203-209.

Gill, S. A., Alfson, E. D. and Hau, M. 2007. Context matters: female aggression and testosterone in a year-round territorial neotropical songbird (Thryothorus leucotis). - Proc. R. Soc. B 274: 2187-2194.

Goymann, W., Wittenzellner, A., Schwabl, I. and Makomba, M. 2008. Progesterone modulates aggression in sex-role reversed female African black coucals. - Proc. R. Soc. B 275: 1053-1060.

Grafen, A. 1990. Biological signals as handicaps. - J. Theor. Biol. 144: 517-546.

Hau, M. 2007. Regulation of male traits by testosterone: implications for the evolution of vertebrate life histories. - BioEssays 29: 133-144.

Hau, M., Wikelski, M., Soma, K. K. and Wingfield, J. C. 2000. Testosterone and year-round territorial aggression in a tropical bird. - Gen. Comp. Endocrinol. 117: 20-33.

Hill, G. E., Hood, W. R. and Huggins, K. 2009. A multifactorial test of the effects of carotenoid access, food intake and parasite load on the production of ornamental feathers and bill coloration in American goldfinches. - J. Exp. Biol. 212: 1225-1233.

Jawor, J. M. M., Young, R. L. and Ketterson, E. D. 2006. Females competing to reproduce: dominance matters but testosterone may not. - Horm. Behav. 49: 362-368.

Johnsen, T. S. and Zuk, M. 1995. Testosterone and aggression in male red jungle fowl. - Horm. Behav. 29: 593-598.

Jones, I. L. and Hunter, F. M. 1999. Experimental evidence for mutual inter- and intrasexual selection favouring a crested auklet ornament. - Anim. Behav. 57: 521-528.

Karubian, J., Lindsay, W. R., Schwabl, H. and Webster, M. S. 2011. Bill coloration, a flexible signal in a tropical passerine bird, is regulated by social environment and androgens. Anim. Behav. 81: 795-800.

Kelly, R. J., Murphy, T. G., Tarvin, K. A. and Burness, G. 2012 Carotenoid-based ornaments of female and male American goldfinches (Spinus tristis) show sex-specific correlations with immune function and metabolic rate. - Physiol. Biochem. Zool. 85: 348-363.

Ketterson, E. D., Nolan, V. Jr and Sandell, M. 2005. Testosterone in females: mediator of adaptive traits, constraint on sexual dimorphism, or both? - Am. Nat. 166: S85-S98.

Kraaijeveld, K., Gregurke, J., Hall, C., Komdeur, J. and Mulder, R. A. 2004. Mutual ornamentation, sexual selection, and social dominance in the black swan. - Behav. Ecol. 15: 380-389.

Kraaijeveld, K., Kraaijeveld-Smit, F. J. L. and Komdeur, J. 2007. The evolution of mutual ornamentation. - Anim. Behav. 74: 657-677.

Langmore, N. E., Davies, N. B., Hatchwell, B. J. and Hartley, I. R. 1996. Female song attracts males in the alpine accentor Prunella collaris. - Proc. R. Soc. B 263: 141-146.

Langmore, N. E., Cockrem, J. F. and Candy, E. J. 2002. Competition for male reproductive investment elevates testosterone 
levels in female dunnocks, Prunella modularis. - Proc. R. Soc. B 269: 2473-2478.

Laucht, S., Kempenaers, B. and Dale, J. 2010. Bill color, not badge size, indicates testosterone-related information in house sparrows. - Behav. Ecol. Sociobiol. 64: 1461-1471.

Ligon, J. D., Thornhill, R., Zuk, M. and Johnson, K. 1990. Male-male competition, ornamentation and the role of testosterone in sexual selection in red jungle fowl. - Anim. Behav. 40: 367-373.

Lyon, B. E. and Montgomerie, R. 2012. Sexual selection is a form of social selection. - Phil. Trans. R. Soc. B 367: 2266-2273.

Martínez-Padilla, J., Mougeot, F., Webster, L. M. I., Pérez-Rodríguez, L. and Piertney, S. B. 2010. Testing the interactive effects of testosterone and parasites on carotenoid-based ornamentation in a wild bird. - J. Evol. Biol. 23: 902-913.

McGlothlin, J. W., Jawor, J. M. M., Greives, T. J., Casto, J. M., Phillips, J. L. and Ketterson, E. D. 2008. Hormones and honest signals: males with larger ornaments elevate testosterone more when challenged. - J. Evol. Biol. 21: 39-48.

McGraw, K. J. 2006. Sex steroid dependence of carotenoidbased coloration in female zebra finches. - Physiol. Behav. 88: 347-352.

McGraw, K. J. and Hill, G. E. 2000. Differential effects of endoparasitism on the expression of carotenoid- and melanin-based ornamental coloration. - Proc. R. Soc. B 267: 1525-1531.

McGraw, K. J. and Parker, R. S. 2006. A novel lipoproteinmediated mechanism controlling sexual attractiveness in a colorful songbird. - Physiol. Behav. 87: 103-108.

McGraw, K. J. and Middleton, A. L. A. 2009. American goldfinch (Spinus tristis). - In: Poole, A. (ed.), The birds of North America online. Cornell Lab of Ornithology.

McGraw, K. J., Hill, G. E., Navara, K. J. and Parker, R. S. 2004. Differential accumulation and pigmenting ability of dietary carotenoids in colorful finches. - Physiol. Biochem. Zool. 77: 484-491.

McGraw, K. J., Correa, S. M. and Adkins-Regan, E. 2006. Testosterone upregulates lipoprotein status to control sexual attractiveness in a colorful songbird. - Behav. Ecol. Sociobiol. 60: 117-122.

Møller, A. P., Garamszegi, L. Z., Gil, D., Hurtrez-Boussès, S. and Eens, M. 2005. Correlated evolution of male and female testosterone profiles in birds and its consequences. - Behav. Ecol. Sociobiol. 58: 534-544.

Montgomerie, R. 2006. Analyzing colors. - In: Hill, G. E. and McGraw, K. J. (eds), Bird coloration vol. 1: mechanisms and measurements. Harvard Univ. Press, pp. 70-147.

Montgomerie, R. 2010. RCLR, ver. 0.9.33 colour analysis using R.

Muck, C. and Goymann, W. 2011. Throat patch size and darkness covaries with testosterone in females of a sex-role reversed species. - Behav. Ecol. 22: 1312-1319.

Mundinger, P. C. 1972. Annual testicular cycle and bill color change in the eastern American goldfinch. - Auk 89: 403-419.

Murphy, T. G., Hernández-Muciño, D., Osorio-Beristain, M., Montgomerie, R. and Omland, K. E. 2009a. Carotenoidbased status signaling by females in the tropical streak-backed oriole. - Behav. Ecol. 20: 1000-1006.

Murphy, T. G., Rosenthal, M. F., Montgomerie, R. and Tarvin, K. A. 2009b. Female American goldfinches use carotenoid-based bill coloration to signal status. - Behav. Ecol. 20: 1348-1355.

Nespor, A. A., Lukazewicz, M. J., Dooling, R. J. and Ball, G. F. 1996. Testosterone induction of male-like vocalizations in female budgerigars (Melopsittacus undulatus). - Horm. Behav. 30: 162-169.

Pärn, H., Lindström, K. M., Sandell, M. and Amundsen, T. 2008. Female aggressive response and hormonal correlates - an intrusion experiment in a free-living passerine. - Behav. Ecol. Sociobiol. 62: 1665-1677.

Popp, J. W. 1987. Risk and effectiveness in the use of agonistic displays by American goldfinches. - Behaviour 103: 141-156.

Pryke, S. R. and Andersson, S. 2003. Carotenoid-based epaulettes reveal male competitive ability: experiments with resident and floater red-shouldered widowbirds. - Anim. Behav. 66: 217-224.

Pyle, P. 1997. Identification guide to North American birds - part 1. - Slate Creek Press.

Rohwer, S. 1975. The social significance of avian winter plumage variability. - Evolution 29: 593-610.

Rohwer, S. 1977. Status signaling in harris sparrows: some experiments in deception. - Behaviour 61: 107-129.

Rohwer, S. and Rohwer, F. C. 1978. Status signaling in harris sparrows: experimental deceptions achieved. - Anim. Behav. 26: $1012-1022$

Rosen, R. F. and Tarvin, K. A. 2006. Sexual signals of the male American goldfinch. - Ethology 112: 1008-1019.

Rosenthal, M. F., Murphy, T. G., Darling, N. and Tarvin, K. A. 2012. Ornamental bill color rapidly signals changing condition. - J. Avian Biol. 43: 553-564.

Rosvall, K. A. 2013. Life history tradeoffs and behavioral sensitivity to testosterone: an experimental test when female aggression and maternal care co-occur. - PLoS One 8: e 54120.

Rubenstein, D. R. 2012. Sexual and social competition: broadening perspectives by defining female roles. - Phil. Trans. R. Soc. B 367: 2248-2252.

Sandell, M. I. 2007. Exogenous testosterone increases female aggression in the European starling (Sturnus vulgaris). - Behav. Ecol. Sociobiol. 62: 255-262.

Sandell, M. I. and Smith, H. G. 1997. Female aggression in the European starling during the breeding season. - Anim. Behav. 53: $13-23$

Searcy, W. A. 1988. Do female red-winged blackbirds limit their own breeding densities? - Ecology 69: 85-95.

Senar, J. C. 2006. Color displays as intrasexual signals in birds. - In: Hill, G. E. and McGraw, K. J. (eds), Bird coloration vol. 2: function and evolution. Harvard Univ. Press, pp. 87-136.

Soma, K. K. 2006. Testosterone and aggression: berthold, birds and beyond. - J. Neuroendocrinol. 18: 543-551.

Stokes, A. W. 1950. Breeding behavior of the goldfinch. - Wilson Bull. 62: 107-127.

Swaddle, J. P. and Witter, M. S. 1995. Chest plumage, dominance and fluctuating asymmetry in female starlings. - Proc. R. Soc. B 260: 219-223.

Tarvin, K. A. and Murphy, T. G. 2012. It isn't always sexy when both are bright and shiny: considering alternatives to sexual selection in elaborate monomorphic species. - Ibis 154: 439-443.

Tobias, J. A., Montgomerie, R. and Lyon, B. E. 2012. The evolution of female ornaments and weaponry: social selection, sexual selection and ecological competition. - Phil. Trans. R. Soc. B 367: 2274-2293.

Washburn, B. E., Millspaugh, J. J., Morris, D. L., Schulz, J. H and Faaborg, J. 2007. Using a commercially available enzyme immunoassay to quantify testosterone in avian plasma. - Condor 109: 181-186.

Watson, N. L. and Simmons, L. W. 2010. Reproductive competition promotes the evolution of female weaponry. - Proc. R. Soc. B 277: 2035-2040.

West-Eberhard, M. J. 1979. Sexual selection, social competition, and evolution. - Proc. Am. Phil. Soc. 123: 222-234.

West-Eberhard, M. J. 1983. Sexual selection, social competition, and speciation. - Q. Rev. Biol. 158: 155-183.

Wingfield, J. C., Hegner, R. E., Dufty, A. M. Jr and Ball, G. F. 1990. The "challenge hypothesis": theoretical implications for patterns of testosterone secretion, mating systems, and breeding strategies. - Am. Nat. 136: 829-846.

Wolf, L. L. 1969. Female territoriality in a tropical hummingbird. - Auk 86: 490-504.

Zysling, D. A., Greives, T. J., Breuner, C. W., Casto, J. M., Dernas, G. E. and Ketterson, E. D. 2006. Behavioral and physiological responses to experimentally elevated testosterone in female dark-eyed juncos (Junco hyemalis carolinensis). - Horm. Behav. 50: 200-207. 